\title{
RELEVANT PROBLEMS OF THE CORRELATION BETWEEN THE CONCEPT AND CONTENT OF THE RIGHT TO FREEDOM OF CONSCIENCE AND RELIGION
}

\author{
Dariia Melnykova* \\ Institute of International Relations, International Law Department of Taras Shevchenko, National \\ University of Kyiv, Ukraine,E-mail: daria.melnikova733@gmail.com
}

\section{(Received: February 2021; Accepted: April 2021; Published: May 2021)}

\begin{abstract}
The right to freedom of conscience and religion is a fundamental natural right, which is enshrined in international legal acts and acts of national legislation. At the same time, the different regulation of the mentioned right in distinct acts attracts attention. Variations include the "right to freedom of thought, conscience and religion", "the right to freedom of conscience and confession" etc. This article analyzes all cases of terminological regulation of the right to freedom of conscience and religion. The content of each of the categories is analyzed, due to which the concept of the right to freedom of conscience and religion is defined and a clear distinction is made between each of the categories. Along with this, the interaction of the content and the concept of the right to freedom of conscience and religion is established. Based on the research conducted within the article, the most successful concept for expressing the content of the right to freedom of conscience and religion is determined. The article also analyzes the rulings of the European Court of Human Rights on the vision of the content and concept of the right to freedom of conscience and religion.
\end{abstract}

Keywords: freedom, right; negative right; principle; conscience; religion; belief; international legal instrument.

\section{Introduction}

The right to freedom of conscience and religion is enshrined as a fundamental natural right in international legal instruments and acts of national legislation. In today's globalized world there is a tendency to pluralize the religious environment. There is a rapid increase in the number of denominations, religious movements, trends, movements. Along with this, the number of interfaith conflicts is growing, which determines the need to consider the concept and content of the right to freedom of conscience and religion. This issue is of particular importance for Ukraine where many violations of the right to freedom of conscience and

\footnotetext{
*Corresponding author: Dariia Melnykova.E-mail: daria.melnikova733@gmail.com
}

Copyright (C) 2021 The Author(s). Published by VGWU Press

This is an Open Access article distributed under the terms of the Creative Commons BY 4.0 license (Creative Commons - Attribution 4.0 International - CC BY 4.0) which permits unrestricted use, distribution, and reproduction in any medium, provided the original author and source are credited. 
Melnykova, D., (2021)

"Vasile Goldiş" Western University of Arad

Relevant Problems of the Correlation Between the Concept and Content of the Right to Freedom of Conscience and Religion

religion have been confirmed, in particular, by inciting religious hatred, passing unconstitutional laws, raiding and looting temples, etc.

The right to freedom of conscience and religion is a complex cross-sectoral institute that is regulated both at the universal, regional, and national levels. The complexity of determining the nature of this institute and its place in the system of guarantees of human rights and freedoms due to the difficulty of clearly defining the concept and content of the right to freedom of conscience and religion, which form this institute. These two categories are interrelated, so their research should take place in inseparable unity.

The institute of the right to freedom of conscience and religion, with its components: content, and concept, should be considered within the system of guarantees of human rights and freedoms. The guarantee system, in turn, includes two subsystems: international and national. The subsystem of international guarantees has two levels that are complementary rather than competing with each other, namely the universal and regional levels. Within this system, it is assumed that there should be unity of the institute, and consequently the unity of the concept of the right to freedom of conscience and religion at both levels, by detailing the general provisions of the universal level at the regional level, which clearly regulates the right to freedom of conscience and religion by adapting the provisions to the special conditions of its local development. At the same time, the primary element of the guarantee system is the national level, which clearly defines the institute of the right to freedom of conscience and religion within a state.

Within the above-mentioned subsystems, namely international and national, the concept of the right to freedom of conscience and religion is not regulated in the same way. The concept of the right to freedom of conscience and religion is expressed by different terminological categories and their combination. A natural question arises as to whether different regulations affect the content of the right to freedom of conscience and religion, as these two categories form a single institution. To deal with this, it is necessary to clearly define the category of the concept of the right to freedom of conscience and religion and the aspects it covers.

\section{Methodology of the problem}

Conventionally, all approaches to defining the concept of the right to freedom of conscience and religion can be divided into two categories. The criterion for such a division is, respectively, the primacy or secondary nature of the concept of the right to freedom of conscience and religion in relation to its content.

Thus, if the concept of the right to freedom of conscience and religion is secondary to its content, the terminological regulation must correspond to those aspects that are covered by the content of the right. That is, first the content of the right is required establishment, and then the terminological regulation should be defined, which should be fixed in order to most accurately express the content, and which should then be detailed by regulations. When applying this approach to the definition of the concept of the right to freedom of conscience and religion, there is a scientific method of deduction, since we consider from the general the content, to a more specific - the concept. It would be reasonable to call such an approach to define the concept of the right to freedom of conscience and religion deductive. 
Melnykova, D., (2021) Religion

The other approach is, accordingly, diametrically opposed to the deductive. It consists of the secondary content in relation to the concept of the right to freedom of conscience and religion. Thus, the primary is the terminological regulation of the concept of the right to freedom of conscience and religion, which later determines its content. Terminological regulation is based upon the doctrinal interpretation of the main terminological categories of the institute and is aimed not at reflecting clear content, as in the application of the deductive approach, but rather the limits of defining the content, which should be determined on the basis of terminological regulation of the right to freedom of conscience and religion. In applying this approach, there is the use of induction as the scientific method, from the specific - concept, the consideration traces to a more general - content. Thus, this approach to defining the meaning of the concept of the right to freedom of conscience and religion could be considered inductive.

At the same time, proponents of the unity of categories of content and the concept of the right to freedom of conscience and religion consider these categories as inseparable, i.e. as a single element, which is the concept of the right to freedom of conscience and religion. In fact, the concept of the right to freedom of conscience and religion covers its content. However, this approach is purely doctrinal and has no practical implementation. After all, the complete unity of concept and content is practically impossible. The content is the regulation of the concept, its detailing and external expression. Therefore, the content of the right to freedom of conscience and religion is a multifaceted category that cannot be covered by a single concept.

Previously considered deductive and inductive approaches are quite one-sided. After all, in one case, namely using a deductive approach, the concept of the right to freedom of conscience and religion is completely dependent on the content. Otherwise, using an inductive approach, the content is placed in complete dependence on the concept of the right to freedom of conscience and religion. In turn, the concept is defined on the basis of doctrinal interpretations that are not unified and that would inevitably cause difficulties in determining the content of the right to freedom of conscience and religion, and therefore its place in the system of human rights guarantees.

We consider the institute of the right to freedom of conscience and religion within a single integrated system of guarantees of human rights and freedoms. The concept of institutional unity best meets the criteria for consideration from the standpoint of a systematic approach. This approach lies in that the concept and content of the right to freedom of conscience and religion form a single institute that exists within the system of guarantees of human rights and freedoms, and therefore must be considered in inseparable unity. Unlike the doctrinal concept, the concept and content of the right to freedom of conscience and religion do not form a single right concept, they are inseparable from each other to ensure the existence of the institute of the right to freedom of conscience and religion. However, they are different elements, and only upon the condition of the institutional character of a right, it can become part of the international system of guarantees of human rights and freedoms. It is the systemic approach of institutional unity that makes it possible to overcome the one-sidedness of deductive and inductive approaches. After all, the formation of the content and concept of the right to freedom of conscience and religion as a single institute, determines their

46 sciendo Journal of Legal Studies Volume 27 Issue 41/2021 ISSN 2457-9017; Online ISSN 2392-7054.

Web: publicatii.uvvg.ro/index.php/jls. Pages $44-58$ 
Relevant Problems of the Correlation Between the Concept and Content of the Right to Freedom of Conscience and Religion

interaction, without determining the primacy or secondary nature in their relation to each other.

\section{The correlation between the content and concepts (belief, religion, faith, conscience, confession, worldview) of the right to freedom of conscience and religion}

Given our choice to apply the approach of institutional unity terminological categories that form the concept of the right to freedom of conscience and religion and their subsequent delimitation shall be considered. Since we consider the concept of the right to freedom of conscience and religion within a single institute of law, it is appropriate to consider the terminological regulation of the concept of the right to freedom of conscience and religion within the system of guarantees of human rights and freedoms.

Legal acts at various levels contain the following forms of enshrining the right to freedom of conscience and religion: "the right to freedom of thought, conscience and religion" (Article 18 of the Universal Declaration of Human Rights, Article 18 of the International Covenant on Civil and Political Rights, Article 1 of the Declaration on the Elimination of All Forms of Intolerance and of Discrimination Based on Religion or Belief, Article 14 of the UN Convention on the Rights of the Child, Article 9 of the Convention for the Protection of Human Rights and Fundamental Freedoms); "Freedom of religion" (UN Charter); "The right to profess and practice one's religion" (Article 2 of the Declaration on the Rights of Persons Belonging to National or Ethnic, Religious and Linguistic Minorities, paragraph 19 of the Vienna Declaration and Programme of Action); " Freedom of conscience, the profession and free practice of religion" (Article 6 of the African Charter on Human and Peoples' Rights); "The right to freedom of conscience and religion" (Article 12 of the American Convention on Human Rights); "The right to manifest his or her religion or belief" (Article 8 of the Framework Convention for the Protection of National Minorities), " The freedom of the individual to profess and practice, alone or in community with others, religion or belief acting in accordance with the dictates of his own conscience " ("Final Act of the Conference on Security and Cooperation in Europe");; "The right to freedom of freedom of worldview and confession" (Article 35 of the Constitution of Ukraine).

Thus, based on the above variations of the terminological regulation of the concept of the right to freedom of conscience and religion, it can be argued that the approach within the system of guarantees of human rights and freedoms is not unique and is complicated by different combinations of terminological categories.

In legal doctrine, along with the above differences in the regulation of the concept of the right to freedom of conscience and religion, there is also no single approach to the terminological definition of this concept. Among the variations, scholars use: "the right to freedom of conscience and confession"; "the right to freedom of conscience"; "the right to freedom of religion"; "the right to religious freedom"; "the right to freedom of world perception"; "the right to freedom of thought"; "the right to freedom of conscience and religion", etc.

Analyzing the above variations of terminological regulations of the concept of the right to freedom of conscience and religion draws attention to the combination in different variations of the following terms: "conscience"; "confession"; "religion"; "faith"; "belief"; "opinion"; 
Melnykova, D., (2021)

Relevant Problems of the Correlation Between the Concept and Content of the Right to Freedom of Conscience and Religion

"thought"; "worldview"; "world perception". Based on this, each category needs consideration and clear demarcation.

Consider the basic term in this domain - "religion". There are three approaches to determining its content: formal-legal, theological and doctrinal. In general, doctrinal approaches are divided into essential (determine the essence of religion) and descriptive (which determine the characteristics of religion, by finding common or different features to unite into one category). The difference in approaches determines the heterogeneity of the definition of the term "religion", within the doctrinal aspect, and determines its complexity and diversity.

Let's proceed with the consideration of a theological approach. The term "religion" was adopted by Christians. They gave the term a new meaning. "Religion" in Christianity meant only Christianity, for all other beliefs used a single unifying category "paganism". The first extension of the term "religion" in Christianity took place in the context of the division into "true religion" - that is, Christianity, and "false religions" - "paganism". This division is clearly distinguished in the work of St. Augustine "On true religion.".

Despite the significant number of doctrinal definitions of the term "religion" and the peculiarities of the theological approach, in 1993 there was an attempt to give it a formal legal meaning. The UN Human Rights Committee has tried to provide a definition of "religion". According to the General Comment №22 "On Freedom of Thought, Conscience and Religion" - "religion" was defined as "theological, non-theological and atheistic beliefs, as well as the right not to accept any religion or belief". It follows that the category of religion covers the internal (forum internum) aspect of the content of the right to freedom of conscience and religion. Also, with the help of such a definition of the term "religion", the issue of belonging to "freedom from religion" was resolved, which directly facilitates the distinction between the categories of "freedom of religion" and "freedom of conscience".

Despite the existence of a legal definition of the term "religion" in the legal field, the term "freedom of religion" is generally accepted. The term "freedom of religion" at the regional level is defined in the Judgment of the European Court of Human Rights, namely Buscarini and Others v. San Marino, which states that freedom of religion implies, in particular, the freedom to adhere to a religion or not, to accept or not to accept it. The position that "freedom of religion" covers the category of "freedom from religion" is also confirmed in the case Alexandridis v. Greece. Thus, the term "freedom of religion" covers the freedom to have or not to have a religion, to accept or not to accept it, and, accordingly, this category includes "freedom from religion".

Consider the distinction between the terms "religion" and "faith." Religion, although it belongs to the internal aspect (forum internum), but in essence is an external manifestation. Religion is the result of a certain activity. Instead, faith is a process that results in religion as an inner conviction. Thus, these categories in their unity form the internal aspect (forum internum) of the right to freedom of conscience and religion. The terminological category "faith" is not appropriate for use as a way of regulating the right to freedom of conscience and religion, because it is only a process of forming the internal aspect (forum internum), and not its result.

Regarding the distinction between the categories "religion" and "belief". The category "religion" covers traditional religions and practices derived from traditional religions. 
Relevant Problems of the Correlation Between the Concept and Content of the Right to Freedom of Conscience and Religion

Instead, the category of "belief" covers all other religious views and beliefs. "Belief" is also defined as an integral part of the worldview and intellectual components of religion. However, as stated in the General Comment №22 "On Freedom of Thought, Conscience and Religion", the categories "religion" and "belief" should be interpreted broadly, the latter should not refer exclusively to traditional religions or their practices, to moreover, the mentioned distinction between these two categories should not affect their place in the system of guarantees of human rights and freedoms, as well as otherwise determine any difference between them.

Since the terminological category "religion" belongs to the internal aspect (forum internum) of the right to freedom of conscience and religion, it is by its legal nature freedom. Consideration of this fact is necessary to distinguish between the categories of "freedom of religion" and "religious freedom". In the doctrine quite often the terms "freedom of religion" and "religious freedom" are commonly identified. Indeed, in their lexical meaning, these categories are synonymous. At the same time, applying a formal - legal approach, one could assure that the term "religious freedom" is not correct. In itself, "freedom" is a form of legal nature. By combining the categories of "religious freedom" is the leveling of the legal nature of the category of freedom, because the legal category of "freedom" is given a certain property, namely religiosity, which eliminates its legal nature. Based on this, the category of "religious freedom" in no way reflects the internal aspect (forum internum) of the right to freedom of conscience and religion, as it does not have the legal nature of freedom, and in essence, reflects only certain freedom within religion. However, the above thesis is not reflected in the system of guarantees of human rights and freedoms. Therefore, the use of terminological categories "religious freedom" to define the internal aspect of the content of the right to freedom of conscience and religion is not appropriate, because this category is not legal in its content.

Meanwhile, the application of the theological approach confirms the thesis that "religious freedom" encompasses the freedom of choice within religion. Namely, this thesis is confirmed in the Declaration on Religious Freedom (DIGNITATIS HUMANAE), which was adopted during the Second Vatican Council. This Declaration defines the meaning of the term "religious freedom". It is defined as freedom in matters of religion. From this one could conclude about the inner nature of "religious freedom", i.e. the freedom to form views within religion. At the same time, examining the content of "religious freedom", the Declaration on Religious Freedom states that all people should be free from coercion, both by individuals and social groups, as well as by there was no human authority to force anyone to act against their own conscience in religious matters and to prevent them from acting in accordance with their own conscience, both in private and in public life, both personally and in community with others. Thus, based on this definition, "religious freedom" is seen as freedom in "religious matters", which can be understood as freedom within a particular religion, rather than general "freedom of religion", which includes the ability to have or accept a religion. In addition, it should be emphasized that in the theological approach of the Roman Catholic Church, the terminological category of "religious freedom" has replaced the categories of "freedom of religion" and "freedom of confession", as the latter is not recognized within the theological approach. Thus, according to the theological approach, "religious freedom" is 
Melnykova, D., (2021)

Relevant Problems of the Correlation Between the Concept and Content of the Right to Freedom of Conscience and Religion

defined as freedom of choice within a particular religion. Based on this definition of the terminological category "religious freedom", it can be argued that "religious freedom" is part of "freedom of religion", respectively, they are related as part and whole.

At the same time, within the doctrinal approach, the term "religious freedom" is defined somewhat differently. According to this approach, "religious freedom" is defined as freedom from religion. That is, the category "freedom of religion" covers the entire internal aspect (forum internum) of the content of the right to freedom of conscience and religion, namely to have or accept a religion, as well as freedom from religion, as stated above (according to the provisions of General Comment №22), respectively, the category of "religious freedom" covers one of the components of "freedom of religion".

The next category we propose for consideration is "confession". Confession includes the freedom to have a religion or belief, to accept or not to accept it. Thus, it brings this category closer to the term "religion". Considering the terminological features of this category, it should be noted that the term "confession" includes an aspect of professing a religion or belief. Confession, in accordance with Art. 18 of the International Covenant on Civil and Political Rights, is the right to practice one's religion, both individually and jointly with others, publicly or privately, in worship, in the performance of religious and ritual rites and teachings. Thus, we prove that the category of religion includes, along with the internal, the external aspect of the right to freedom of conscience and religion.

As we have already proved, faith is the process by which it is possible to have or accept a religion, which is the result. Thus, the term "faith", although it exists within the internal aspect, is nevertheless directly connected with the procedural aspect of its formation. If faith is an internal process that determines the formation of the internal aspect, then confession is an external process and directly expresses the external aspect of the content of the right to freedom of conscience and religion. Based on it, both categories: "faith", "confession" - are the procedural implementation of internal and external aspects, which determines the unity of these two categories. Without faith as a process, confession is not possible. Based on this, we prove the feasibility of using a single terminological category - "confession".

Consider the terminological category of "beliefs". Beliefs consist of ideas, thoughts, aspirations, evaluations, values that form a single system of human worldview. In this context, belief is only an internal aspect (forum internum) of the right to freedom of conscience and religion. Belief is inalienable freedom of every person, which has an absolute character. However, the term "beliefs" does not encompass the external aspect of its expression, "beliefs" are exclusively absolute freedom, which belongs to every human being and, accordingly, is an internal aspect of the content of the right to freedom of conscience and religion. Instead, the content of the right to freedom of conscience and religion encompasses forum internum and forum externum, which is enshrined in the system of guarantees of human rights and freedoms. Based on this, the use for terminological regulation of the concept of the right to freedom of conscience and religion the term "beliefs" is not appropriate. In the context of the application of the institutional unity approach, the terminological category of "beliefs" will not fully reflect the already defined content of the right to freedom of conscience and religion, thus there will be a one-sided approach.

50 sciendo Journal of Legal Studies Volume 27 Issue 41/2021 ISSN 2457-9017; Online ISSN 2392-7054.

Web: publicatii.uvvg.ro/index.php/jls. Pages $44-58$ 
Relevant Problems of the Correlation Between the Concept and Content of the Right to Freedom of Conscience and Religion

In this context, the categories of "worldview" and "world perception" should be considered. These categories are also closely linked to the intrinsic aspect of the right to freedom of conscience and religion. It will be useful to consider these terminological categories concerning the term "beliefs". Thus, the term "world perception" covers the process and method of forming a system of beliefs, which is directly an internal aspect. The category of "worldview" encompasses a set of beliefs and is a single whole. In fact, the "worldview" is the ultimate system formed as a result of the world perception of beliefs, the totality of which formed the system. Thus, based on this, we could see that these three categories, namely "worldview", "belief", "world perception", by interacting within a single process, form a system of internal values, which is the worldview. Thus, all three categories form a system, which is an internal aspect of the right to freedom of conscience and religion.

Let's move on to consider the category of "conscience". Conscience includes a system of internal values, each person's worldview, which is completely identical to the term "beliefs". However, as already mentioned, the category of "beliefs" includes only the internal aspect (forum internum), while the term "conscience" covers both internal and external aspects of the right to freedom of conscience and religion. Freedom of conscience includes the freedom to choose moral and ethical, philosophical, pacifist, or other beliefs and worldviews of the individual. Conscience is generally defined as a system of internal moral criteria for evaluating one's actions, which regulates expressions and opinions. Thus, this category covers not only the freedom to have an internal system of values, but also the right to act freely per this internal system of beliefs. Therefore, the term "freedom of conscience" fully covers the content of the right to freedom of conscience and religion, in particular its basic elements: internal and external aspect, which proves the feasibility of using the terminological category "conscience" to reflect the concept of freedom of conscience and religion in the system of guarantees and human freedoms.

The next correlation to be considered is the terms "conscience" and "religion". Conscience, as we have already noted, includes a system of inner beliefs, values. Religion is essentially a set of views that form a system of religious beliefs. Freedom of religion is aimed at the sphere of religious faith, belief in the spiritual, sacred, absolute, and part of the beliefs of the individual as a whole. At the same time, the category of conscience is broader, and likewise includes the category of religion as a part, which is one of the elements of the formation of the whole system of worldview. In addition, this position is enshrined in the General Comment №22 of the UN Human Rights Committee "On Freedom of Thought, Conscience and Religion".

The position expressed in the General Comment №22 of the UN Human Rights Committee "On Freedom of Thought, Conscience and Religion" was supported at the regional level in the decision of the European Court of Human Rights. In Kokkinakis v. Greece case, ECHR states that the terminological category of freedom of conscience also covers the right to practice any religion. That is, it actually confirms that the right to freedom of conscience encompasses the right to freedom of religion. In fact, this decision expands the position expressed in the General Comment №22, as it considered only the ratio of "freedom of conscience" and "freedom of religion", which is an internal aspect. Instead, in the case, Kokkinakis v. Greece ECHR examines the relationship between "freedom of conscience" and 
Melnykova, D., (2021)

Relevant Problems of the Correlation Between the Concept and Content of the Right to Freedom of Conscience and Religion

"freedom of religion", which, as defined above, covers both internal and external aspects. In this context, it should be noted the unity of the system of guarantees of human rights and freedoms, namely the complementarity of its elements: at the regional level, the consideration of the relationship between "freedom of conscience" and "freedom of religion" was expanded at the universal level.

Analyzing the broader aspect of the correlation the categories that cover both the internal and external aspects of the content of the right to freedom of conscience and religion namely: "freedom of conscience" and "freedom of confession", it is possible to establish their close relationship. They correlate as a whole and a part, as species and generic concepts.

It has already been emphasized that the institute of the right to freedom of conscience and religion, as part of the system of guarantees of human rights and freedoms, covers two categories: the concept and content of the right to freedom of conscience and religion. Using the approach of institutional unity, we proved that for the effective functioning of the institute of the right to freedom of conscience and religion within the system of international guarantees to regulate the concept of the right to freedom of conscience and religion, it is appropriate to use terminological categories of "conscience" and "confession". These two categories systematically cover both the internal (forum internum) and external (forum externum) aspects of the right to freedom of conscience and religion, which fully express the content of this right.

\section{The legal nature of the right to freedom of conscience and religion}

The category of the concept of the right to freedom of conscience and religion contains two components. The first component - terminological regulation has already been considered and clearly defined, in the context of the existence in the system of guarantees of human rights and freedoms. The second component - the legal nature of the right to freedom of conscience and religion. To systematically consider the concept of the right to freedom of conscience and religion, it is advisable to consider the second component.

Concerning the legal nature, within the system of guarantees of human rights and freedoms and in the existing legal doctrine there is no single approach to determining the legal nature of the right to freedom of conscience and religion. The legal nature is defined within three categories: law, freedom, principle. To determine the legal nature of the right to freedom of conscience and religion, it is necessary to determine the content of each of the categories and correlate it with the content of the right to freedom of conscience and religion.

Consider "freedom" as a category of legal nature. Rene Descartes defined freedom as "autonomy of will", "arbitrariness". In general, in legal science, freedom is defined as something natural that is inherent in every person and that is not related to the normative and practical provision of this by the state and other actors. Freedom is absolute, in the context of the fact that it cannot be restricted by the state, as it lies in the inner plane of human nature. It cannot be violated by other subjects of legal relations. Sometimes an individualistic aspect is introduced to define the legal category of freedom. That is, freedom is something individual, not universal, that belongs to each person. Yes, indeed, freedom cannot be collective, because freedom is only an internal aspect, the realization of which is exclusively individual. However, the meaning of freedom cannot be defined as completely individual. It 
Melnykova, D., (2021)

"Vasile Goldiş" Western University of Arad

Relevant Problems of the Correlation Between the Concept and Content of the Right to Freedom of Conscience and Religion

is individual in the context of perception, but not content. Consider the issue of freedom of religion, religion is not individually tailored to each individual, but there is a difference in perception of religion. At the same time, the absolute nature of freedom, in the context of ensuring the "right to freedom of thought, conscience, religion" is confirmed in the Judgments of the European Court of Human Rights. In particular, in Kokkinakis v. Greece, cited above.

Taking into account all the above signs of freedom, it can be argued that the internal aspect of the right to freedom of conscience and religion is precisely freedom by its legal nature. After all, the internal aspect is absolute, does not depend on the provision of the state, and belongs to every human being from birth. Given the above terminological categories and the established legal nature of the internal aspect, to regulate the internal aspect of the right to freedom of conscience and religion is appropriate as "freedom of religion and belief." After all, these categories cover the internal aspect of the complex categories of "confession" and "conscience", respectively.

Since we have proved that freedom belongs to everyone by nature and does not require any action by the state aimed at its practical implementation, based on this, we can define the category of freedom as a negative right. A negative right is a right based on the ability to demand non-interference in a certain area of one's life. The freedom to have or to accept a religion gives rise to this right but is not inherently it.

Negative right considering the right to freedom of conscience and religion will, in any case, be directed at the external aspect. An example is the compulsion to change religion or beliefs. The right to protection will be negative, as it will be based on the right to ensure noninterference in the sphere of private life and thus to ensure freedom of choice of religion and belief, which is freedom and belongs to the internal aspect. A natural question arises as to why a negative right that is directly related to the category of freedom is in the plane of the external aspect. As already emphasized, freedom of religion is absolute, as it is an intrinsic aspect. From the outside, the inner aspect cannot be influenced by anyone. Even when considering a situation with coercion to change religion or beliefs, there is coercion to external change, because no one can forcibly renounce one's religion or beliefs internally. A similar case was heard by the European Court of Human Rights, namely Ivanova $v$. Bulgaria. The decision states that "forcing a person to change his or her religious beliefs, as well as refraining from such a change or expression of religion or belief, is a violation of the right to freedom of thought, conscience and religion." Thus, we see that the protection is aimed at the external aspect to ensure the internal. That is, the concept of negative law is aimed at protecting the violation of the external manifestation of freedom of religion or belief. The doctrinal concept of negative law, which lies in the external aspect of the content of the right to freedom of conscience and religion, is confirmed by the ECHR in the case Alexandridis v. Greece. The judgment states that "the Court notes that freedom of religion and the right to practice a religion or belief has a negative aspect, namely the right of an individual not to be obliged to express his or her religion or other views or to act in a manner that expresses religion or other beliefs". It follows the attribution of the negative right to the external aspect to protect the internal. The negative right of a person not to practice religion and not to express his convictions is recognized. Firstly, the Judgment of the ECHR refers to 
Melnykova, D., (2021)

Relevant Problems of the Correlation Between the Concept and Content of the Right to Freedom of Conscience and Religion

the "right to profess a religion", which already indicates the consideration of a negative right in the external sphere. Secondly, there is a concretization of what is affected by the negative right, from such concretization it is also possible to conclude the direction of the negative right to protection of external manifestations of the internal aspect of the right to freedom of conscience and religion. Thus, the legal nature of the concept of the right to freedom of conscience and religion covers a form of negative freedom, which is confirmed at the regional level within the system of guarantees of human rights and freedoms.

Let's proceed with the concept of "right" as a form of determining the legal nature of the right to freedom of conscience and religion. The right is an opportunity to take active action enshrined and guaranteed by the state. That is, the right thus lies in the realm of the external aspect. In turn, rights can be positive or negative. Negative right, as already considered, does not provide for active actions aimed at its implementation or provision. It implies the obligation of other subjects not to interfere in the sphere of this negative right and gives rise to the right to demand such non-interference. Thus, in essence, the negative right is close to freedom, but, as already defined, the negative right, as well as the right as a whole, covers only the external manifestation, while freedom covers only the internal.

Let's move on to consider the concept of so-called "positive right". Positive right, in contrast to the negative, provides for active action aimed at its practical implementation and provision. The external manifestation of the implementation of a positive right is active action. Based on this, positive law belongs exclusively to the external aspect. The external aspect (forum externum) of the right to freedom of conscience and religion, which is covered by the terms "conscience" and "confession" is a positive right. After all, the external aspect of law includes, in particular, per Article 18 of the International Covenant on Civil and Political Rights, the practice of one's religion, both individually and jointly with others, publicly or privately, in worship, religious and ritual rites and teachings. It becomes obvious that the external aspect requires both certain actions aimed at implementation and provision. Thus, the external aspect (forum externum) of the right to freedom of conscience and religion is a positive right.

Consider the "principle" as a form of the legal nature of the right to freedom of conscience and religion. The principle is enshrined in law normative - guiding position, which characterizes its content. International legal acts enshrine the principles of "freedom of religion" and the principle of "non-discrimination on the grounds of religion." However, the form of the "principle" has nothing to do with what is guaranteed to man. The principle establishes a normative - guiding position for other subjects, that position which should be guided concerning persons with rights. Thus, the principle is secondary to the rights and freedoms that the human being is endowed with. The principle of "freedom of religion" stipulates that within the state, which is a party to the relevant international legal act, freedom of religion must be ensured for all, but the principle does not give the person any rights.

Thus, the legal category of the principle is of a general nature, which is secondary to freedom and right and does not apply to the subject of realization of the right to freedom of conscience and religion, but to those subjects who ensure this realization. Since the "principle" covers only the external aspect, which, moreover, does not apply to the subject of implementation, respectively, this form of legal nature does not reflect the content of the right to freedom of

54 sciendo Journal of Legal Studies Volume 27 Issue 41/2021 ISSN 2457-9017; Online ISSN 2392-7054.

Web: publicatii.uvvg.ro/index.php/jls. Pages $44-58$ 
Melnykova, D., (2021)

"Vasile Goldiş" Western University of Arad

Relevant Problems of the Correlation Between the Concept and Content of the Right to Freedom of Conscience and Religion

conscience and religion. Based on this, in the context of considering the legal nature of the concept of the right to freedom of conscience and religion, the definition of it as a principle is not appropriate.

\section{Conclusions}

Analyzing all the above aspects of the legal nature of the right to freedom of conscience and religion, we proved that the external aspect (forum externum) of the content of the right to freedom of conscience and religion is a positive right, while the internal aspect (forum internum) of the content of the right to freedom of conscience and religion - is freedom provided by the negative right, which already applies to the external domain. At the same time, the category of the principle is secondary to freedom and right, and lies outside the realm of the content of the right to freedom of conscience and religion, because it is exclusively general in nature. From this, we can conclude that none of the forms of legal nature fully covers the content of the right to freedom of conscience and religion.

In turn, the category of freedom covers the internal aspect, while the right is external. The legal nature of the right to freedom of conscience and religion is complex. It contains two opposite aspects: internal and external. Where the external cannot exist without the internal, and the internal cannot be fully provided without the external (in the context of negative law). The difficulty of determining the legal nature lies in the simultaneous combination of three interrelated elements: freedom, negative right, and positive right. In this regard, freedom clearly indicates the natural aspect, while the right to the positivist. Thus, the institution of the right to freedom of conscience and religion combines both elements of natural and positive law. These facts require a combination of forms of the legal nature of "right" and "freedom" to fully and comprehensively reflect the content of the right to freedom of conscience and religion.

Thus, given the complexity of the two-dimensional institution of the right to freedom of conscience and religion, we determined that this institution of law contains the concept and content of the right to freedom of conscience and religion, which is determined by their interaction. Accordingly, we have chosen the approach of institutional unity to define the concept of the right to freedom of conscience and religion, which is determined by the systemic unity of consideration of the concept and content of the right to freedom of conscience and religion. Using this approach, we found that the category of the concept of the right to freedom of conscience and religion includes aspects of terminological regulation and legal nature. In the context of terminological regulation, we found that two aspects of the content of the right to freedom of conscience and religion fully reflect two categories: "conscience" and "religion", combining them in terms of terminological regulation is necessary to fully and comprehensively reflect the content of the right to freedom of conscience and religion. Regarding the legal nature, we have established its complex nature, which is a combination of internal and external aspects. To fully reflect the content of the right to freedom of conscience and religion, while reflecting the legal nature of the mentioned concept of combination, the forms of legal nature "freedom" and "right" need.

Analyzing the above facts, we argue that the complex category of the concept should be defined as "the right to freedom of conscience and religion." The designation "right to 
Melnykova, D., (2021)

Relevant Problems of the Correlation Between the Concept and Content of the Right to Freedom of Conscience and Religion

freedom" is justified by the fact that to fully ensure the external expression of absolute internal freedom, a negative right is necessary, which, despite ensuring internal character, belongs to the external plane. Based on this, we argued that the concept should be defined as "the right to freedom of conscience and religion", which will most fully express the meaning of this institute.

\section{Acknowledgments}

The author thanks the anonymous reviewers and editor for their valuable contribution.

\section{Funding}

This research received no specific grant from any funding agency in the public, commercial, or not - for - profit sectors.

\section{Author Contributions}

The entire article was written by Melnykova Daria.

\section{Disclosure Statement}

The author has not any competing financial, professional, or personal interests from other parties.

\section{References}

1. Abasidze, A.H. (2012). Regional systems for the protection of human rights. Moscow: Peoples' Friendship University of Russia.

2. Abasidze, A.H. (2013). Universal mechanisms for the protection of human rights. Moscow: Unity - dana.

3. African Union, (1981). African Charter on Human and Peoples' Rights. Retrieved from https://www.achpr.org/legalinstruments/detail?id=49 Accessed on 28 January 2021.

4. Bed, V.V. (2011). International - legal consolidation of freedom of conscience. Journal of Kyiv University of Law, 1, $349-353$.

5. Bulavina, M.A. (2019). Freedom of conscience and freedom of religion: constitutional and legal aspect. Bulletin of the Institute of World Civilizations, 3, $104-108$.

6. Centre for Civil and Political Rights, (1993). General Comment №22: Article 18 (Freedom of Thought, Conscience or Religion). Retrieved from https://www.refworld.org/docid/453883fb22.html. Accessed on 10 January 2021.

7. Council of Europe, (1950). Convention for the Protection of Human Rights and Fundamental Freedoms. Retrieved from https://www.echr.coe.int/documents/convention_eng.pdf Accessed on 28 January 2021.

8. Council of Europe, (1995). Framework Convention for the Protection of National Minorities. Retrieved from https://www.coe.int/en/web/minorities Accessed on 28 January 2021.

56 sciendo Journal of Legal Studies Volume 27 Issue 41/2021 ISSN 2457-9017; Online ISSN 2392-7054. 
Melnykova, D., (2021)

"Vasile Goldiş" Western University of Arad

Relevant Problems of the Correlation Between the Concept and Content of the Right to Freedom of Conscience and Religion

9. Council of Europe, (2015). Handbook on the application of Article 9. Freedom of thought, conscience, and religion. Retrieved from https://www.echr.coe.int/Documents/Guide_Art_9_UKR.pdf Accessed on 28 January 2021. 10. Dakhova, I.I. (2016). The content of the right to freedom of conscience and religion. Forum of law, 4, $107-112$.

11. Declaration on Religious Freedom Dignitatis Humanae. Retrieved from https://cathmos.ru/wp-

content/uploads/2019/12/dokumenty_vtorogo_vatikanskogo_sobora.pdf. Accessed on 28 January 2021.

12. European Court of Human Rights, (1993). Kokkinakis v. Greece. Retrieved from https://hudoc.echr.coe.int/eng\#\{"itemid":["001-57827"]\} Accessed on 24 January 2021.

13. European Court of Human Rights, (1999). Buskarini and Others v. San Marino. Retrieved from

https://hudoc.echr.coe.int/fre\#\{ "languageisocode":["ENG"],"appno":["24645/94"],"docume ntcollectionid2":["GRANDCHAMBER"],"itemid":["001-58915"]\} Accessed on 28 January 2021.

14. European Court of Human Rights, (2007). Ivanova v. Bulgaria. Retrieved from https://hudoc.echr.coe.int/fre\#\{ "languageisocode":["ENG"],"appno":["52435/99"],"docume ntcollectionid2":["CHAMBER"],"itemid":["001-80075"]\} Accessed on 21 January 2021.

15. European Court of Human Rights, (2008). Alexandridis v. Greece. Retrieved from https://hudoc.echr.coe.int/eng-press\#\{"itemid":["003-2274253-2426441"]\} Accessed on 28 January 2021.

16. Final Act of the Conference on Security and Cooperation in Europe (1975). Retrieved from: https://www.osce.org/files/f/documents/5/c/39501.pdf Accessed on 20 January 2021. 17. Koroleva, L.A. (2011). Freedom of conscience and religion: on the question of terms. Historical, philosophical, political, and legal sciences, cultural studies, and art history. Questions of theory and practice, 5, $106-108$.

18. Office of the United Nations High Commissioner, (2011). Rapporteur's Digest on Freedom of Religion or Belief. Retrieved from https://www.ohchr.org/Documents/Issues/Religion/RapporteursDigestFreedomReligionBeli ef.pdf Accessed on 20 January 2021.

19. Organization of American States, (1969). American Convention on Human Rights. Retrieved from https://www.oas.org/dil/treaties_B32_American_Convention_on_Human_Rights.pdf Accessed on 28 January 2021.

20. Proskurnina, A.S. (2012). Freedom of conscience and religion in Russia. Ural: State educational institution of higher professional education "Ural State Law Academy".

21.UN, (1945). Charter of the United Nations. Retrieved from: https://www.un.org/en/charter-united-nations/ Accessed on 20 January 2021.

22. UN, (1966). International Covenant on Civil and Political Rights. Retrieved from: https://www.ohchr.org/EN/ProfessionalInterest/Pages/CCPR.aspx Accessed on 20 January 2021.

23. UN, (1970). Declaration on Principles of International Law Friendly Relations and Cooperation among States in accordance with the Charter of the United Nations and the UN 
Melnykova, D., (2021)

Relevant Problems of the Correlation Between the Concept and Content of the Right to Freedom of Conscience and Religion

\begin{tabular}{llllll}
\hline General Assembly & Resolution & 2625 & (XXU). & Retrieved
\end{tabular}
https://www.un.org/ruleoflaw/files/3dda1f104.pdf. Accessed on 20 January 2021.

24. UN, (1981). Declaration on the Elimination of All Forms of Intolerance and of Discrimination Based on Religion or Belief. Retrieved from https://www.ohchr.org/EN/ProfessionalInterest/Pages/ReligionOrBelief.aspx Accessed on 28 January 2021.

25. UN, (1989). Convention on the Rights of the Child. Retrieved from https://www.ohchr.org/EN/ProfessionalInterest/Pages/CRC.aspx Accessed on 28 January 2021.

26. UN, (1992). Declaration on the Rights of Persons Belonging to National or Ethnic, Religious and Linguistic Minorities. Retrieved from https://www.ohchr.org/en/professionalinterest/pages/minorities.aspx Accessed on 28 January 2021.

27. UN, (1993). Vienna Declaration and Programme of Action. Retrieved from: https://www.ohchr.org/en/professionalinterest/pages/vienna.aspx Accessed on 20 January 2021.

28. UN, (2000). United Nations Millennium Declaration. (2000). Retrieved from: https://www.ohchr.org/EN/ProfessionalInterest/Pages/Millennium.aspx. Accessed on 20 January 2021.

29. Verkhovna Rada of Ukraine, (1996). Constitution of Ukraine. Retrieved from https://zakon.rada.gov.ua/laws/show/254к/96-вp Accessed on 20 January 2021. 